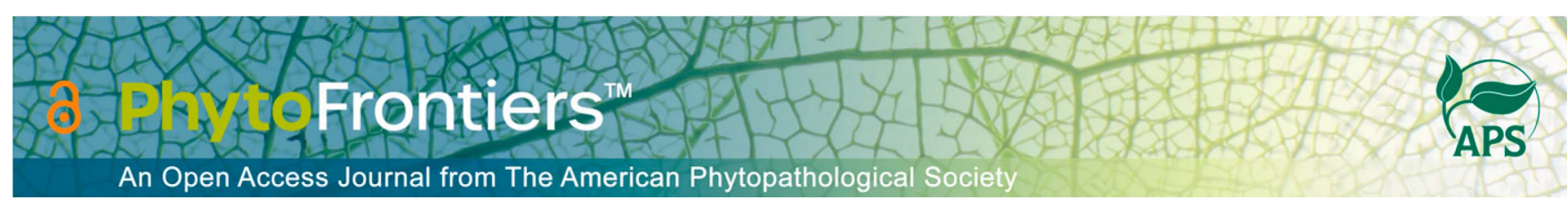

\title{
Research
}

\section{Sensitive and Specific qPCR and Nested RT-PCR Assays for the Detection of Tobacco Streak Virus in Soybean}

\author{
Cristina Zambrana-Echevarría ${ }^{1}$ (1) | Mitchell G. Roth ${ }^{1}$ | Ranjit Dasgupta ${ }^{2}$ | Thomas L. German ${ }^{2}$ | \\ Carol L. Groves ${ }^{1}$ | Damon L. Smith ${ }^{1,+}$ (D) |
}

${ }^{1}$ Department of Plant Pathology, University of Wisconsin-Madison, 1630 Linden Drive, Madison, WI 53706

${ }^{2}$ Department of Entomology, University of Wisconsin-Madison, 1630 Linden Drive, Madison WI 53706

${ }^{\dagger}$ Corresponding author: D. L. Smith; damon. smith@wisc.edu

Accepted for publication 2 April 2021.

\section{Funding}

The study was performed with funding by the Wisconsin Soybean Marketing Board.

$\boldsymbol{e}$-Xtra: Two supplementary tables are available online.

The author(s) declare no conflict of interest.

\begin{abstract}
Tobacco streak virus (TSV) is a reemerging and understudied pathogen of soybean (Glycine max). Management of TSV is challenging due to the multiple modes of transmission, widespread susceptibility of commercial soybean, and lack of reliable diagnostic tests for the virus. Soybean plants with TSV-like, viruslike, or no symptoms were collected from commercial and research fields in seven counties in Wisconsin. Two sensitive assays were developed for the detection of TSV: a fluorescent dye-based quantitative reverse-transcription PCR (qPCR) assay and a nested reverse-transcription PCR (nRT-PCR). TSV was detected in 47 and $91 \%$ of symptomatic samples using the qPCR and nRTPCR assays, respectively, suggesting that the nRT-PCR assay has higher sensitivity for detecting TSV. The qPCR assay's limit of detection was determined at $10 \mathrm{fg}$ and the assay was used to estimate the viral load in TSV-symptomatic samples. The titer of TSV in these samples was determined by absolute quantification and ranged from $15 \mathrm{fg}$ to $0.796 \mathrm{ng}$. The two assays reported here provide diagnostic tools for the rapid and accurate detection of TSV that can aid in monitoring outbreaks, assessing management strategies, or screening soybean cultivars or accessions for resistance to the virus.
\end{abstract}

Keywords: ilarvirus, nested RT-PCR, pathogen detection, qPCR, soybean, tobacco streak virus

Tobacco streak virus (TSV) is the type member of the genus Ilarvirus (Bromoviridae) and the causal agent of bud blight in soybean (Glycine max L. Merrill) in the United States and Brazil (Costa et al. 1955; Fagbenle and Ford 1970). In the United States, TSV was first reported in Iowa and Ohio in soybean plants showing symptoms of stunting, shepherd's crook, delayed maturity, poor pod production, dark green apical leaves with rugosity, necrotic streaks in the stem, and bud blight (Fagbenle and Ford 1970; Johnson 1936, 1943; Melhus 1942). It was subsequently reported in Oklahoma (Sherwood and Jackson 1985), Illinois (Hobbs et al. 2010; 
Wang et al. 2005), and Wisconsin (Rabedeaux et al. 2005). Sporadic reports of the virus suggest that it has not been a widespread problem in commercial soybean fields, or that it has gone underreported. Recently, a reemergence of TSV has been reported in Oklahoma (Dutta et al. 2015), Iowa, and Wisconsin (Irizarry et al. 2016).

TSV is an understudied virus in soybean and the agronomic impacts on the crop are not fully understood (Rabedeaux et al. 2005). The United States is one of the top three soybeanproducing countries in the world (FAOSTAT 2018). In 2019, soybean yields were estimated to be 3.2 metric tons/ha valued at more than US $\$ 30$ billion (USDA-NASS 2019). However, yield losses due to viral diseases have been estimated to be as high as 891,000 metric tons, resulting in US\$1.7 billion in economic losses (Allen et al. 2017; Bandara et al. 2020; Wrather and Koenning 2009). Specifically, TSV has been reported to cause a $10 \%$ reduction in yield in artificially inoculated field studies (Rabedeaux et al. 2005), and there is widespread susceptibility to TSV in soybean accessions and cultivars (Hobbs et al. 2012; Rabedeaux et al. 2005; Wang et al. 2005). Moreover, infected plants are commonly noticed at the end of the growing season due to delayed maturity caused by TSV infection. The latency in which TSV symptoms are expressed in soybean is a feature shared with other ilarviruses (Pallas et al. 2012, 2013).

The genome of TSV is a tripartite, positive-sense singlestrand RNA contained in a nonenveloped spherical or quasispherical particle (Bujarski et al. 2019). RNA 1 and RNA 2 encode the components of the viral replicase, while RNA 3 encodes the movement protein ( $\mathrm{Ge}$ et al. 1997; Pallas et al. 2013; Scott et al. 1998; Xin et al. 1998). A subgenomic RNA 4 is expressed from RNA 3 to produce the coat protein $(\mathrm{CP})$ (Cornelissen et al. 1984), a structural protein that is involved in viral pathogenesis and other biological processes (Bol 1999; van Vloten-doting 1975). TSV has a worldwide distribution and a broad host range, with species in over 30 families that include weeds, ornamentals, vegetables, fruit, and field crops (Abtahi and Motlagh 2009; Dijkstra 1983; Gracia and Feldman 1974; Kaiser et al. 1982; Padmanabhan et al. 2014; Sharman et al. 2008, 2015; Sivaprasad et al. 2010; Vemana and Jain 2010; Vemana et al. 2014; Vinodkumar et al. 2017; Wells-Hansen et al. 2016).

The spread of ilarviruses occurs vertically via the seed or horizontally through infected pollen transmitted by insect vectors (Card et al. 2007; Mink 1992, 1993). Seed transmission of TSV has been reported in weeds and leguminous hosts (Fagbenle and Ford 1970; Ghanekar and Schwenk 1974; Kaiser et al. 1982, 1991). Rates of TSV seed transmission of up to $90 \%$ have been reported in soybean and varies depending on the cultivar (Fagbenle and Ford 1970; Ghanekar and Schwenk 1974; Kaiser et al. 1982, 1991). Infected seed contribute to the initial inoculum of the virus in the field and results in random clusters of infected plants (Ghanekar and Schwenk 1974). Another transmission pathway of TSV involves insect vectors, where several species of thrips (Thysanoptera: Thripidae) have been reported to assist in the transmission of the virus by moving infected pollen (Kaiser et al. 1982; Klose et al. 1996; Prasada Rao et al. 2003; Sdoodee and Teakle 1987, 1993; Sharman et al. 2015). A study by Almeida and Corso (1991) found that thrips feeding on pollen from weed reservoirs spread TSV into soybean fields and the spread within fields occurred after an increase in thrips populations. The within-field spread by thrips resulted in a clustered distribution of TSV-infected plants (Almeida and Corso (1991).
Management of viral-induced diseases depends on reliable, sensitive, and rapid diagnostic tools (Rubio et al. 2020). The various transmission pathways of TSV and the latency of symptom expression in soybean highlights the importance of developing detection methods as diagnostic tools for management of the virus. Serological detection methods such as enzyme-linked immunosorbent assay and dot-immunobinding assay have been used for detection of TSV (Ali 2017; Sharman et al. 2008). However, ilarviruses have been reported to cause disease at low titers (Osman et al. 2014; Untiveros et al. 2010) and serological tests have failed to reliably detect TSV in plants (Ali 2017). These methods have lower sensitivity and decreased ability to detect low viral titers compared with nucleic acid amplification (Boonham et al. 2008; Schneider et al. 2004; Untiveros et al. 2010). PCR is a highly specific nucleic acid amplification method commonly used in diagnostic tests for ilarviruses (Osman et al. 2014; Untiveros et al. 2010), with increased sensitivity compared with serological tests (Rubio et al. 2020). The objective of this study was to develop a quantitative reverse-transcription PCR (qPCR) assay and a nested reverse-transcription PCR (nRT-PCR) assay for the sensitive and specific detection of TSV in soybean. Both assays were compared as diagnostic tools for TSV, and the qPCR assay developed here was compared with a previously published qPCR assay (Dutta et al. 2015). The titer of TSV in the study samples was estimated with the qPCR assay.

\section{MATERIALS AND METHODS}

\section{Sample processing}

Soybean plants showing symptoms of TSV, including shepherd's crook, stunting, poor to no pod production, stem necrotic streaks, pod blight (on plants that produced pods), and top dieback, were received by University of WisconsinMadison's Plant Disease Diagnostic Clinic in 2019 from production fields in Iowa and Dodge Counties in Wisconsin (Table 1). Additional soybean plants with TSV-like symptoms, other viral-like symptoms, or no symptoms were collected from research fields in Wisconsin from 2016 to 2019 (Table 1). Approximately $100 \mathrm{mg}$ of soybean leaf tissue was ground to a fine powder in liquid nitrogen using a mortar and pestle. Total RNA was extracted using the TRIzol Plus RNA Purification Kit (Invitrogen, Carlsbad, CA, U.S.A.) or the Maxwell RSC Plant RNA kit with the automated Maxwell RSC Instrument (Promega Corp., Madison, WI, U.S.A.) according to the manufacturers' instructions. RNA quantity was estimated on a NanoDrop UV-Vis Spectrophotometer (Thermo Fisher Scientific, Waltham, MA, U.S.A.). RNA ( $1 \mu \mathrm{g})$ was used for RT of first-strand complementary DNA (cDNA) using $5 \times$ iScript Reverse Transcription Supermix (Bio-Rad, Hercules, CA, U.S.A.) with random hexamer priming according to the manufacturer's instructions. The cDNA was diluted to a 1:10 ratio for an estimated final concentration of $5 \mathrm{ng} / \mu \mathrm{l}$ for downstream use.

\section{qPCR assay design}

The primers TSVCP_Fw1 and TSVCP_Rv1 (Table 2) were designed using Primer3 (Rozen and Skaletsky 2000) and the sequence of a TSV isolate (GenBank accession number JX073658.1) to amplify $137 \mathrm{bp}$ of the TSV CP gene. qPCR was performed in $20-\mu \mathrm{l}$ reactions with the following 
conditions: $10 \mu \mathrm{l}$ of $2 \times$ SsoFast EvaGreen Supermix (Bio$\mathrm{Rad}), 0.8 \mu \mathrm{l}(10 \mu \mathrm{M})$ of each primer, $4.4 \mu \mathrm{l}$ of nuclease-free water, and $4 \mu \mathrm{l}$ of cDNA ( $5 \mathrm{ng} / \mu \mathrm{l})$. PCR and fluorescence reading were performed in a CFX96 Real-Time PCR detection system (Bio-Rad). The cycling conditions consisted of $30 \mathrm{~s}$ of denaturation at $95^{\circ} \mathrm{C}$, followed by 35 cycles of $5 \mathrm{~s}$ of denaturation at $95^{\circ} \mathrm{C}, 5 \mathrm{~s}$ of annealing or extension at $61^{\circ} \mathrm{C}$, and a final cycle of a melt curve in $0.5^{\circ} \mathrm{C}$ increments from 55 to $95^{\circ} \mathrm{C}$. Each qPCR experiment consisted of two technical replicates per sample loaded to a 96-well skirted, clear-well microplate (Bio-Rad)

\section{qPCR assay sensitivity}

To determine the sensitivity of the qPCR assay, the target sequence corresponding to the TSV CP gene was cloned into a plasmid. The cDNA from the Wisconsin TSV isolate, W101-4 (Table 1), was amplified with the primer pair TSVCP_Fw1/TSVCP_Rv1 using RT-PCR. The reaction consisted of $12.5 \mu \mathrm{l}$ of $2 \times$ GoTaq Master Mix (Promega Corp.), $2.5 \mu \mathrm{l}(10 \mu \mathrm{M})$ of each primer, and $7.5 \mu \mathrm{l}$ of cDNA $(5 \mathrm{ng} / \mu \mathrm{l})$. The PCR was performed in an Eppendorf MasterCycler Pro S programmable thermal cycler (Eppendorf AG, Hamburg, Germany) using the following cycling conditions: $2 \mathrm{~min}$ of denaturation at $95^{\circ} \mathrm{C}$; followed by 35 cycles of $30 \mathrm{~s}$ of denaturation at $95^{\circ} \mathrm{C}, 30 \mathrm{~s}$ of annealing at $57^{\circ} \mathrm{C}$, and $45 \mathrm{~s}$ of elongation at $72^{\circ} \mathrm{C}$; followed by a final extension step of 5 min at $72^{\circ} \mathrm{C}$. PCR fragments were visualized by electrophoresis in $1 \times$ Tris-acetate-EDTA (TAE) on a $1.2 \%$ agarose gel containing SYBR Safe DNA gel stain (Life Technologies, Carlsbad, CA, U.S.A.) using a 1-kb DNA Ladder (Promega Corp.) to estimate the size. The 137-bp PCR fragment of interest was excised from the gel and purified using the Wizard SV Gel and PCR Clean up System (Promega Corp.). The amplicon was cloned into pGEM-T using the pGEM-T Easy Vector System I (Promega Corp.) according to the manufacturer's instructions. The resulting plasmid was transformed into Escherichia coli strain DH5 $\alpha$ using heat-shock transformation and subsequent selections made on LuriaBertani (LB) agar amended with ampicillin at $100 \mu \mathrm{g} / \mathrm{ml}, 0.5$ $\mathrm{mM}$ isopropyl- $\beta$-D-thiogalactoside, and 5-bromo-4-chloro-3indolyl- $\beta$-D-galactopyranoside at $80 \mu \mathrm{g} / \mathrm{ml}$. White colonies were selected and confirmed for the presence of pGEM-T containing the TSV insert (pGEM-T-TSV) via colony PCR using the TSV Fw1/Rv1 primer pair. A single PCR-positive colony was incubated in LB broth amended with ampicillin at 100 $\mu \mathrm{g} / \mathrm{ml}$ overnight at $37^{\circ} \mathrm{C}$ with shaking at $200 \mathrm{rpm}$. The plasmid pGEM-T-TSV was purified using the ZR Plasmid Miniprep Classic kit (Zymo Research, Irvine, CA, U.S.A.) according to the manufacturer's instructions. Plasmid copy number was calculated using the calculator by Staroscik (2004) with the DNA concentration (nanograms per microliter) and length of pGEM-T-TSV (3,157 bp). A qPCR standard curve was generated by making 10 -fold serial dilutions of pGEM-T-TSV. The dilution series ranged from 100 copies to $1.0 \times 10^{9}$ copies of plasmid, which is equivalent to $1 \mathrm{fg}$ to 10 ng. The qPCRs containing the standard curve were replicated three times on independent plates. The threshold cycle $(\mathrm{Ct})$ values of each dilution standard were averaged among the technical replicates per plate (Supplementary Table S1). The efficiency of the assay was calculated by linear regression of the standard curve and the equation $E=10^{(-1 / \text { slope) }}-1$ (Bustin et al. 2009; Pfaffl 2001). The limit of detection was determined when $95 \%$ of samples were detected at the lowest concentration (Bustin et al. 2009).

\section{qPCR assay validation and specificity}

The qPCR primers were optimized with an annealing temperature gradient and melt curve analysis of a 1:10 dilution of pGEM-T-TSV. Annealing temperatures tested ranged from 57 to $61^{\circ} \mathrm{C}$. A melt curve peak temperature of $81^{\circ} \mathrm{C}$ was considered a TSV-positive sample in the qPCR assay. Selected study samples were amplified by RT-PCR with the TSVCP_Fw1/ TSVCP_Rv1 primer pair (reaction mixture components and cycling conditions described in the previous section) and Sanger-sequenced to confirm TSV in the PCR product (Supplementary Table S2). Samples previously confirmed with RT-PCR to be positive for soybean vein necrosis virus (SVNV), alfalfa mosaic virus (AMV), and bean pod mottle virus (BPMV) were tested with the qPCR assay to assess the specificity for detecting TSV. Detection of these viruses was achieved by RT-PCR using previously published primers (Xu and Nie 2006) and primers designed by the authors of this study. Reactions substituting cDNA with nuclease-free water and a no-RT control were included on each plate as negative

\section{TABLE 1}

Sample designation, symptom type, location of collection, and year of collection for soybean samples used in the study for detecting tobacco streak virus with quantitative reverse-transcription PCR and nested reverse-transcription PCR and comparing the assays

\begin{tabular}{|c|c|c|c|}
\hline Sample & Symptoms, virus & Location $^{\mathrm{a}}$ & Year \\
\hline $201-1$ & Virus-like & Columbia & 2016 \\
\hline $201-2$ & Virus-like & Columbia & 2016 \\
\hline $201-3$ & Virus-like & Columbia & 2016 \\
\hline $201-4$ & Virus-like & Columbia & 2016 \\
\hline W101-1 & Virus-like & Columbia & 2016 \\
\hline W101-2 & Virus-like & Columbia & 2016 \\
\hline W101-3 & Virus-like & Columbia & 2016 \\
\hline W101-4 & Virus-like & Columbia & 2016 \\
\hline D1 & TSV-like & Columbia & 2018 \\
\hline D4 & TSV-like & Columbia & 2018 \\
\hline D5 & TSV-like & Columbia & 2018 \\
\hline D6 & TSV-like & Columbia & 2018 \\
\hline LS1 & TSV-like & Rusk & 2018 \\
\hline LS2 & TSV-like & Rusk & 2018 \\
\hline 107 & Asymptomatic & Chippewa & 2019 \\
\hline 112 & TSV-like & Grant & 2019 \\
\hline 122 & Asymptomatic & Chippewa & 2019 \\
\hline 215 & TSV-like & Chippewa & 2019 \\
\hline 310 & TSV-like & Chippewa & 2019 \\
\hline 413 & TSV-like & Columbia & 2019 \\
\hline 423 & Asymptomatic & Columbia & 2019 \\
\hline 427 & TSV-like & Columbia & 2019 \\
\hline $319-1$ & TSV-like & Columbia & 2019 \\
\hline SB1 & TSV-like & Dodge & 2019 \\
\hline SB2 & TSV-like & Dodge & 2019 \\
\hline SB3 & TSV-like & Dodge & 2019 \\
\hline SB4 & TSV-like & Dodge & 2019 \\
\hline SB5 & TSV-like & Dodge & 2019 \\
\hline SB6 & TSV-like & Dodge & 2019 \\
\hline SB7 & TSV-like & Dodge & 2019 \\
\hline SB8 & TSV-like & Iowa & 2019 \\
\hline SB9 & TSV-like & Iowa & 2019 \\
\hline W04-1 & TSV-like & Dane & 2019 \\
\hline W04-2 & TSV-like & Dane & 2019 \\
\hline W04-3 & TSV-like & Dane & 2019 \\
\hline W04-4 & TSV-like & Dane & 2019 \\
\hline
\end{tabular}

${ }^{a}$ County in the state of Wisconsin. 
(no-template) controls. A healthy soybean plant (DwNT1) grown in a controlled environment room was also tested with the qPCR assay to asses off-target amplification. The absolute quantification of the TSV CP gene was calculated by CFX Maestro Software 1.1 (Bio-Rad) with the equation $10^{\left(\frac{C t-b}{m}\right)}$, where $C t$ is the threshold cycle of the sample and $b$ and $m$ are the $y$-intercept and slope, respectively, of the pGEM-T-TSV standard curve linear regression.

\section{nRT-PCR}

Nested primers targeting the TSV CP gene were designed using the IDT PrimerQuest Tool (https://www.idtdna.com/ Primerquest) and the sequence of a TSV isolate (GenBank accession number DQ864458.1). The primers TSVCP12F1 and TSVCP715R1 (Table 2) were used for the first-round PCR. The reaction consisted of $12.5 \mu \mathrm{l}$ of $2 \times$ GoTaq Master Mix, $2.5 \mu \mathrm{l}(10 \mu \mathrm{M})$ of each first-round primer, and $7.5 \mu \mathrm{l}$ of cDNA $(5 \mathrm{ng} / \mu \mathrm{l})$. The second-round PCR included the primers TSVCP39F2 and TSVCP681R2 (Table 2), which are internal to TSVCP12F1/TSVCP715R1. The reaction mixture consisted of $12.5 \mu \mathrm{l}$ of $2 \times$ GoTaq Master Mix, $2.5 \mu \mathrm{l}(10 \mu \mathrm{M})$ of each primer, $2.5 \mu \mathrm{l}$ of nuclease-free water, and $5 \mu \mathrm{l}$ of the PCR product from the first round. The following cycling conditions were used in an Eppendorf MasterCycler Pro S programmable thermal cycler for each PCR round: 1 min of denaturation at $95^{\circ} \mathrm{C}$; followed by 40 cycles of $20 \mathrm{~s}$ of denaturation at $95^{\circ} \mathrm{C}$, $30 \mathrm{~s}$ of annealing at $54^{\circ} \mathrm{C}$, and $45 \mathrm{~s}$ of elongation at $72^{\circ} \mathrm{C}$; followed by a final extension step of $10 \mathrm{~min}$ at $72^{\circ} \mathrm{C}$. The PCR products were visualized by electrophoresis in $1 \times$ TAE on a 1 . $2 \%$ agarose gel containing SYBR Safe DNA gel stain using a 1-kb DNA ladder to estimate fragment size. The expected product sizes were $700 \mathrm{bp}$ in the first round and of $643 \mathrm{bp}$ in the second round. The resulting products were Sanger sequenced with the nested primers. The nucleotide basic local alignment search tool (BLAST) (https://blast.ncbi.nlm.nih.gov/ Blast.cgi) was used to confirm sequence identity as belonging to TSV (Supplementary Table S2). The samples previously confirmed to be positive for common soybean viruses, described in the previous section, and the healthy soybean control DwNT1 were tested with the nRT-PCR primers to assess off-target amplification. Selected study samples and the healthy control were subjected to RNA extraction and cDNA synthesis as described above, then tested with RT-PCR and primers for the Glycine max elongation factor $1-\beta$ (Table 2 ) to confirm RNA extraction and cDNA synthesis of the healthy control. The reaction components were used as described previously for first-round RT-PCR. The PCR was performed in an Eppendorf MasterCycler Pro S thermal cycler with the following cycling conditions: $2 \mathrm{~min}$ of denaturation at $95^{\circ} \mathrm{C}$; followed by 35 cycles of 1 min of denaturation at $94^{\circ} \mathrm{C}, 30 \mathrm{~s}$ of annealing at $50^{\circ} \mathrm{C}$, and $1 \mathrm{~min}$ of elongation at $72^{\circ} \mathrm{C}$; followed by a final extension step of $5 \mathrm{~min}$ at $72^{\circ} \mathrm{C}$.

\section{Comparative qPCR}

The qPCR primers TSV1789Fnd and TSV1982Rnd designed by Dutta et al. (2015) (Table 2), which target the CP gene of TSV, were used to assess the detection of TSV in soybean samples collected in Wisconsin and to compare its performance with the PCR tools developed in this study. The PCR was performed in a CFX96 real-time PCR detection system (Bio-Rad) using a reaction mixture that consisted of $10 \mu \mathrm{l}$ of $2 \times$ SsoFast EvaGreen Supermix, $0.8 \mu \mathrm{l}(10 \mu \mathrm{M})$ of each primer, $4.4 \mu \mathrm{l}$ of nuclease-free water, and $4 \mu \mathrm{l}$ of cDNA ( $5 \mathrm{ng} /$ $\mu \mathrm{l})$. The cycling conditions consisted of $30 \mathrm{~s}$ of denaturation at $95^{\circ} \mathrm{C}$ for, followed by 35 cycles of $5 \mathrm{~s}$ of denaturation at $95^{\circ} \mathrm{C}, 5 \mathrm{~s}$ of annealing or extension at $56^{\circ} \mathrm{C}$, and a final cycle of a melt curve in $0.5^{\circ} \mathrm{C}$ increments from 55 to $95^{\circ} \mathrm{C}$.

\section{RESULTS}

\section{qPCR assay sensitivity}

Serial dilutions of the plasmid pGEM-T-TSV were used to determine the sensitivity of the qPCR assay by generating a standard curve tested on three replicate PCR plates. The cloned fragment of the CP gene of TSV was detected at concentrations as low as $1 \mathrm{fg}$ (Fig. 1; Supplementary Table S1). However, the limit of detection of the assay (Bustin et al. 2009) was set at $10 \mathrm{fg}$ or at a $\mathrm{Ct}=32$, because the $1-\mathrm{fg}$ samples were detected with higher variability (Fig. 1; Supplementary Table S1). Therefore, $10 \mathrm{fg}$ is the concentration where a reliable detection $(>95 \%)$ of the target can be achieved in this qPCR assay (Bustin et al. 2009).

\section{qPCR assay validation}

The TSVCP_Fw1 and TSVCP_Rv1 primer set was optimized with an annealing or extension temperature gradient, melt curve peak analysis, and a test of efficiency. The optimal annealing or extension temperature was assessed with a gradient of $2^{\circ} \mathrm{C}$ increments. All temperatures tested in the gradient generated amplification curves with $\mathrm{Ct}$ values between 10 and 11 and a uniform melt curve with a peak at $81^{\circ} \mathrm{C}$ indicating amplification of the correct target (Fig. 2). However, $61^{\circ} \mathrm{C}$ was chosen as the optimal annealing and extension temperature

TABLE 2

DNA sequence and thermodynamics of primers used in this study

\begin{tabular}{|c|c|c|c|c|}
\hline Primer name & Sequence $\left(5^{\prime}-3^{\prime}\right)$ & $\mathrm{Tm}^{\mathrm{a}}$ & Length (bp) & Reference \\
\hline TSV_Fw1 & CCAACGACGCAATCCCTTTC & 59.8 & 20 & This study \\
\hline TSV_Rv1 & GCCCGTTACTCCATCAACCA & 60 & 20 & This study \\
\hline TSVCP39F2 & GATCCAAAGTCCAGACCATCCA & 56.6 & 22 & This study \\
\hline TSVCP681R2 & AGTCTTGATTCACCAGGAAATCTTC & 54.9 & 25 & This study \\
\hline TSVCP12F1 & CGCCATGTCTTCTCGTACTAAC & 55.2 & 22 & This study \\
\hline TSVCP715R1 & AAGGGAGCTGGTTTGGATATG & 54.8 & 21 & This study \\
\hline TSV1789Fnd & GCTATCGTCTGCAGCCTCGA & 59.3 & 20 & Dutta et al. 2015 \\
\hline TSV1982Rnd & CCACATCGCACACAGGAATT & 55.8 & 20 & Dutta et al. 2015 \\
\hline GmELF1BF & CAACTTGCTCCAAGCTTTCC & 54.5 & 20 & A. Ranjan, unpublished \\
\hline GmELF1BR & AGGGTGTCCACGGATACAAG & 56.6 & 20 & A. Ranjan, unpublished \\
\hline
\end{tabular}

${ }^{\mathrm{a}} \mathrm{Tm}=$ melting temperature $\left({ }^{\circ} \mathrm{C}\right)$ calculated by Primer3 and IDT's OligoAnalyzer tool. 
because it did not negatively affect the $\mathrm{Ct}$ values by increasing them. Furthermore, the $61{ }^{\circ} \mathrm{C}$ annealing temperature consistently led to higher $\mathrm{Ct}$ values or $\mathrm{Ct}$ values equal to zero in the nuclease-free water controls (Fig. 2A) and no peak in the melt curve analysis (Fig. 2B). The efficiency of the reaction was calculated with the slope of the regression line from the 10-fold serial dilutions of pGEM-T-TSV. The average efficiency of three independent replicate PCR plates containing the serial dilutions was $94 \%$, with an $R^{2}=0.998$ (Fig. 1).

\section{qPCR assay specificity}

To ensure that the qPCR assay reported here (WI qPCR) did not cross-react with other common viruses found in soybean, samples previously confirmed for SVNV, AMV, and

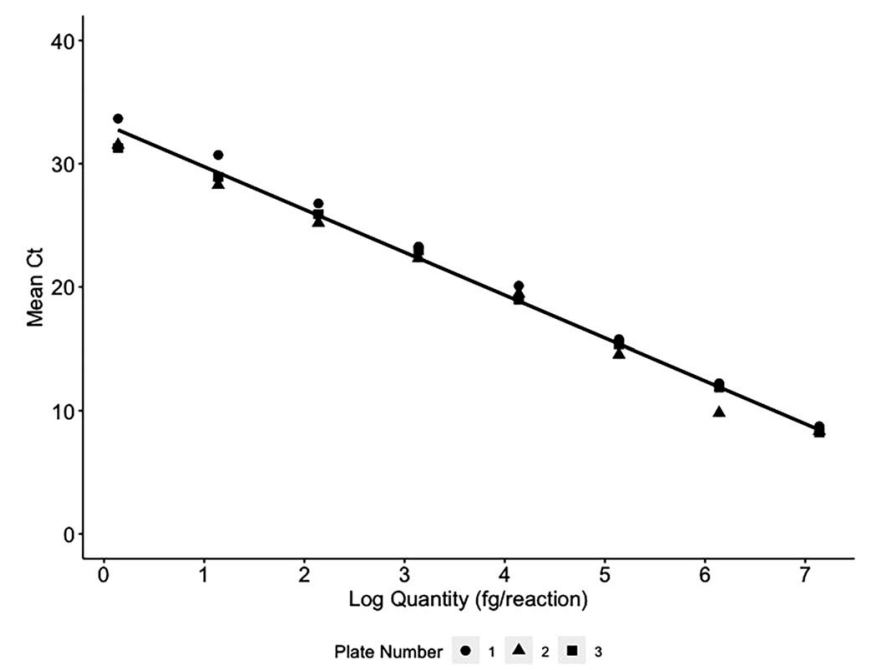

FIGURE 1

Concentration and threshold cycle $(\mathrm{Ct})$ of serial dilutions of pGEM-T-tobacco streak virus. Three independent replicate plates were used to generate the equation $y=-3.47 x+33.22$, $R^{2}=0.998$. Mean Ct was calculated based on two technical replicates per serial dilution per plate.

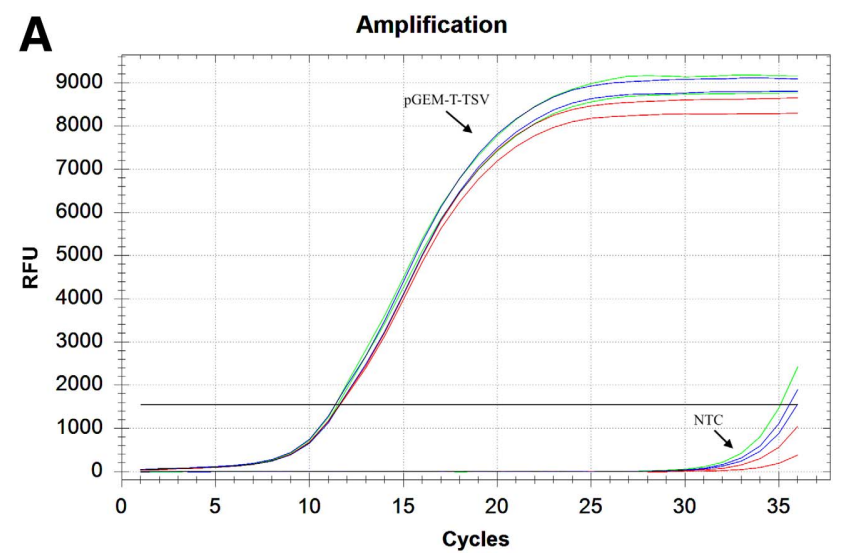

BPMV via RT-PCR were used to determine the specificity of the qPCR assay for TSV. The SVNV sample (Ar2), AMV sample (102-8-1), BPMV sample (B1), and the asymptomatic samples had undetermined $\mathrm{Ct}$ values or values $>34$ (Table 3 ) and no melt curve peak (Fig. 3A). The nuclease-free water (no-template control [NTC]) and no-reverse-transcription (NRT) controls had undetermined $\mathrm{Ct}$ values and did not produce a peak in the melt curve (Table 3; Fig. 3A). A healthy soybean control (DwNT1) was tested with the qPCR assay and yielded undetermined $\mathrm{Ct}$ values and no melt curve peak (Fig. 3B). The amplification of TSV by the WI qPCR primer pair TSV_Fw1/Rv1 was confirmed by DNA sequencing and nucleotide BLAST of selected samples. The sequences had 94 to $97 \%$ similarity to TSV isolates from Wisconsin and Iowa (Supplementary Table S2).

Additionally, 34 soybean plants showing TSV- or viral-like symptoms and 3 asymptomatic plants were tested with the qPCR for the presence of TSV. Sixteen samples yielded $\mathrm{Ct}$ values $\leq 32.5$ and a melt curve peak of $81^{\circ} \mathrm{C}$ (Table 3 ). These samples are above the limit of detection and were deemed positive for TSV. The samples 201-1, 201-4, SB4, SB7, and W101-1 resulted in $\mathrm{Ct}$ values $>33$, did not produce a melt curve peak, and were deemed negative for TSV (Table 3). TSV titer was measured in the samples using the serial dilutions of pGEM-T-TSV and it ranged from $15 \mathrm{fg}$ to $0.796 \mathrm{ng}$ (Fig. 4). The samples W101-2, SB9, and 427 had the lowest titers of the virus $(15,17$, and $19 \mathrm{fg}$, respectively) and were just above the limit of detection (10 fg) of the assay. No concentration of TSV was detected in the samples confirmed for SVNV, AMV, or BPMV. No asymptomatic TSV infection was found using the WI qPCR assay in the samples without viral symptoms.

\section{nRT-PCR}

The amplification of the TSV CP by the nRT-PCR was confirmed by Sanger-sequencing and performing a nucleotide BLAST of the sequences. The sequences generated had 99 to $100 \%$ identity to TSV (Supplementary Table S2). Following the confirmation that the nested primers amplify the TSV CP, the detection of TSV by the nRT-PCR was assessed in the samples from Wisconsin. Samples previously confirmed to be

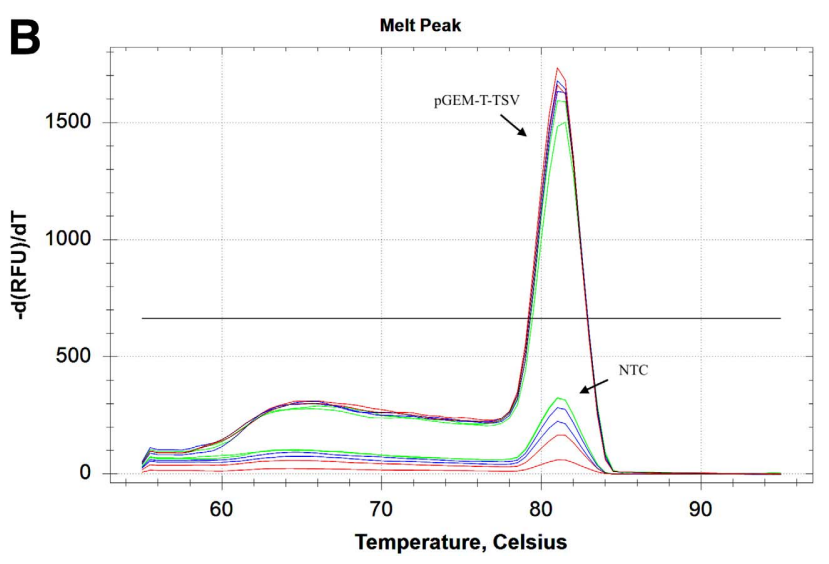

FIGURE 2

Amplification curve and melt curve analysis of annealing temperature gradient of TSVCP_Fw1 and TSVCP_Rv1 primers with pGEM-Ttobacco streak virus (TSV) used as the DNA template. A, Amplification curves at $57^{\circ} \mathrm{C}$ (blue line), $59^{\circ} \mathrm{C}$ (green line), and $61^{\circ} \mathrm{C}$ (red line). No-template control (NTC: nuclease-free water) was used at each of the temperatures and yielded threshold cycle values greater than 35. B, A single peak at $81^{\circ} \mathrm{C}$ on the melt curve indicates a single PCR product. NTC showed a melt curve peak below threshold. 
positive for AMV, SVNV, and BPMV were negative in the nRT-PCR (Table 3). Similar to the WI qPCR assay, the nRTPCR assay is specific for detecting TSV and does not crossreact with other viruses of soybean. The nuclease-free water (NTC) controls, the NRT control, and the healthy soybean control did not produce bands at the expected size of 643 to $700 \mathrm{bp}$ and were negative in the nRT-PCR (Table 3; Fig. 3C and D), despite confirmation of RNA quality and cDNA synthesis in these samples (Fig. 3E). This assay detected TSV in 31 of 34 TSV-like or virus-like symptomatic samples, compared with 16 of 34 with the WI qPCR assay (Table 2). None of the asymptomatic samples was positive with the nRT-PCR.

\section{Comparative qPCR}

A comparison of the detection specificity by the WI qPCR and nRT-PCR assays reported in this study with the set of qPCR primers (Dutta qPCR) reported previously by Dutta et al. (2015) was made. The study samples were tested with the

TABLE 3

Detection of tobacco streak virus (TSV) in soybean samples by the quantitative reverse-transcription PCR (WI qPCR) and nested reverse-transcription (nRT-PCR) assays described in this study and comparison with the previously published qPCR assay (Dutta qPCR)

\begin{tabular}{|c|c|c|c|c|c|}
\hline \multirow[b]{2}{*}{ Sample $^{\mathrm{a}}$} & \multicolumn{2}{|c|}{ Mean $\mathrm{Ct}^{\mathrm{b}}$} & \multicolumn{3}{|c|}{ Assay result ${ }^{\mathrm{c}}$} \\
\hline & WI qPCR & Dutta qPCR & WI qPCR ${ }^{\mathrm{d}}$ & Dutta $\mathrm{qPCR}^{\mathrm{e}}$ & nRT-PCR ${ }^{f}$ \\
\hline $201-1$ & $34.91 \pm 0.00^{*}$ & $6.58 \pm 3.79 *$ & - & - & + \\
\hline $201-2$ & $19.52 \pm 0.02$ & $32.91 \pm 0.08$ & + & - & + \\
\hline $201-3$ & $20.14 \pm 0.02$ & $32.66 \pm 0.20$ & + & - & + \\
\hline $201-4$ & $34.91 \pm 0.00^{*}$ & udt & - & - & + \\
\hline W101-1 & $35.14 \pm 0.27^{*}$ & udt & - & - & + \\
\hline W101-2 & $32.56 \pm 0.16$ & udt & + & - & + \\
\hline W101-3 & $29.65 \pm 0.10$ & udt & + & - & + \\
\hline W101-4 & $16.78 \pm 0.50$ & $30.48 \pm 0.05$ & + & + & + \\
\hline D1 & udt & udt & - & - & + \\
\hline D4 & udt & $9.65 \pm 3.41^{*}$ & - & - & + \\
\hline D5 & $23.11 \pm 0.04$ & $30.98 \pm 0.24$ & + & + & + \\
\hline D6 & udt & udt & - & - & + \\
\hline LS1 & udt & udt & - & - & + \\
\hline LS2 & udt & udt & - & - & + \\
\hline 107 & udt & udt & - & - & - \\
\hline 112 & $28.37 \pm 0.07$ & udt & + & - & + \\
\hline 122 & udt & udt & - & - & - \\
\hline 215 & udt & udt & - & - & - \\
\hline 310 & udt & udt & - & - & + \\
\hline 413 & $31.02 \pm 0.31$ & $29.77 \pm 0.13$ & + & + & + \\
\hline 423 & udt & $30.19 \pm 0.03$ & - & + & - \\
\hline 427 & $32.25 \pm 0.00$ & udt & + & - & + \\
\hline $319-1$ & udt & udt & - & - & + \\
\hline SB1 & $25.84 \pm 0.04$ & $34.68 \pm 0.26$ & + & - & + \\
\hline SB2 & $27.4 \pm 0.13$ & $33.78 \pm 0.24$ & + & - & + \\
\hline SB3 & $25.7 \pm 0.04$ & $33.69 \pm 0.21$ & + & - & + \\
\hline SB4 & $33.6 \pm 0.15^{*}$ & udt & - & - & + \\
\hline SB5 & $25.58 \pm 0.21$ & $33.41 \pm 0.12$ & + & - & + \\
\hline SB6 & $28.00 \pm 0.04$ & udt & + & - & + \\
\hline SB7 & $34.15 \pm 0.04^{*}$ & udt & - & - & + \\
\hline SB8 & $30.37 \pm 0.01$ & udt & + & - & + \\
\hline SB9 & $32.41 \pm 0.03$ & udt & + & - & + \\
\hline W04-1 & udt & udt & - & - & + \\
\hline W04-2 & udt & udt & - & - & + \\
\hline W04-3 & udt & udt & - & - & - \\
\hline W04-4 & udt & udt & - & - & - \\
\hline $102-8-1$ & $34.41 \pm 0.22^{*}$ & udt & - & - & - \\
\hline Ar2 & udt & udt & - & - & - \\
\hline $\mathrm{B} 1$ & $34.59 \pm 0.07^{*}$ & $33.69 \pm 0.05$ & - & - & - \\
\hline NRT & udt & udt & - & - & - \\
\hline NTC & udt & udt & - & - & - \\
\hline
\end{tabular}

${ }^{a}$ Samples 102-8-1 = alfalfa mosaic virus sample; Ar2 = soybean vein necrosis virus sample; B1 = bean pod mottle virus sample; NRT = no-reverse transcription control; and NTC = no-template control (nuclease-free water).

${ }^{\mathrm{b}}$ Average threshold cycle $(\mathrm{Ct})$ of two technical replicates \pm standard error and udt $=$ undetermined $\mathrm{Ct}$, no template detected.

${ }^{\mathrm{c}}$ Symbols: plus sign (+) or minus sign (-) indicate the sample was positive or negative, respectively, for TSV.

${ }^{\mathrm{d}}$ The following criteria were used to determine WI qPCR assay results: sample was positive if the Ct value $\leq 32$ and the melt curve peak is at $81{ }^{\circ} \mathrm{C}$. If a Ct value was produced but there was no melt curve peak $(*)$, then the sample was considered negative.

${ }^{\mathrm{e}}$ The following criteria were used to determine Dutta qPCR assay results: sample was positive if the $\mathrm{Ct}$ value $\leq 31$ and the melt curve peak is at $84^{\circ} \mathrm{C}$. If a $\mathrm{Ct}$ value was produced but there was no melt curve peak $\left({ }^{*}\right)$, then the sample was considered negative.

${ }^{\mathrm{f}}$ The assay result of the nRT-PCR assay was determined after visual inspection of products separated on an agarose gel and size estimated using a 1-kb molecular ladder. A sample was determined positive if the product size was at $700 \mathrm{bp}$ in the first-round PCR or at $643 \mathrm{bp}$ in the second round. If no product was obtained at the expected size of each round, then the sample was considered negative. 
Dutta qPCR primers and only 4 of 34 samples produced $\mathrm{Ct}$ values between 28 and 30 and a melt curve peak at 83.5 to $84^{\circ} \mathrm{C}$ (Table 3) and were determined to be TSV positive based on these parameters. Three of the positive samples (W101-4, D5, and 413) were TSV or virus symptomatic while the third positive sample (423) was asymptomatic (Table 1). The samples W101-4, D5, and 413 were also positive in the WI qPCR and nRT-PCR; however, the $\mathrm{Ct}$ values were similar or higher in the Dutta qPCR compared with the WI qPCR (Table 3). Eight samples with TSV-like or virus-like symptoms that were positive in the WI qPCR produced $\mathrm{Ct}$ values but no melt curve peak using the Dutta qPCR assay and were determined to be TSV negative (Table 3). The rest of the study samples had undetermined $\mathrm{Ct}$ values and no melt curve peak using the Dutta qPCR assay. Of the asymptomatic samples (Table1), only 423 were positive in the Dutta qPCR and negative in the WI qPCR and nRT-PCR. The AMV sample, SVNV sample, and BPMV sample were negative using the Dutta qPCR assay, corroborating the specificity of the WI qPCR and nRT-PCR assays (Table 3).

\section{DISCUSSION}

TSV is an ilarvirus that affects pod and seed production and plant maturity in soybean. Spread of the virus is aided by its wide host range, thrips-assisted pollen transmission, and seed transmission (Ghanekar and Schwenk 1974; Kaiser et al.
1982, 1991; Sdoodee and Teakle 1987, 1993). TSV infection and transmission strategies can have detrimental effects on soybean production in the United States. Although the agronomic impacts of TSV in soybean are not well studied, yield reduction and contribution to annual yield losses have been documented (Allen et al. 2017; Bandara et al. 2020; Rabedeaux et al. 2005; Wrather and Koenning 2009). The latency of symptom expression with TSV infections make scouting and disease management challenging. Reliable detection is an essential tool for the management of plant viruses (Lévesque 2001; Martin et al. 2000; Rubio et al. 2020). The use of the qPCR and nRT-PCR assays can aid in the implementation of management strategies such as monitoring the field spread of the TSV, planting resistant cultivars, and rogueing infected plants to prevent potential yield losses and maintain healthy seed production fields. Here, we report two sensitive nucleic acid amplification-based assays that target the CP gene of TSV in an effort to expand the molecular diagnostic tools available for detecting TSV in soybean.

The performance of the qPCR assay developed in this study (WI qPCR) was measured by assessing the amplification efficiency, optimum annealing temperature, and melt curve peak analysis. The robustness of the WI qPCR assay was assessed with the amplification efficiency determined from the linear regression of the standard curve. Optimum PCR efficiency ranges from 90 to $110 \%$, low PCR efficiency $(<90 \%)$ can result from contamination, and high PCR efficiency $(>110 \%)$

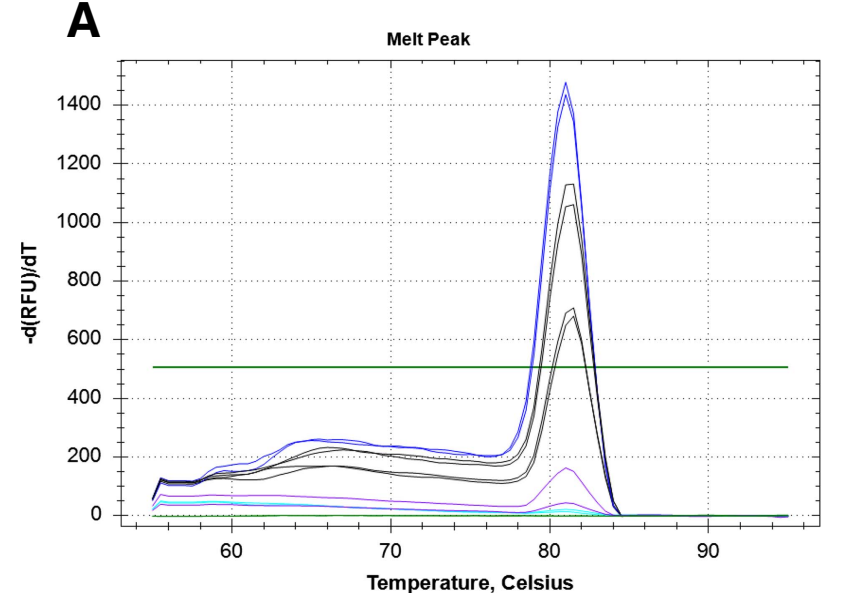

C

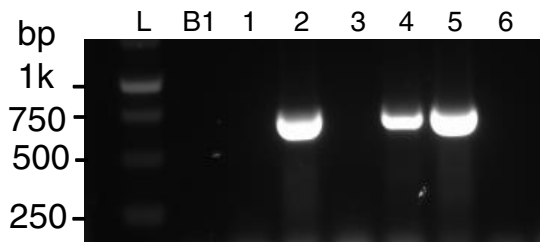

B

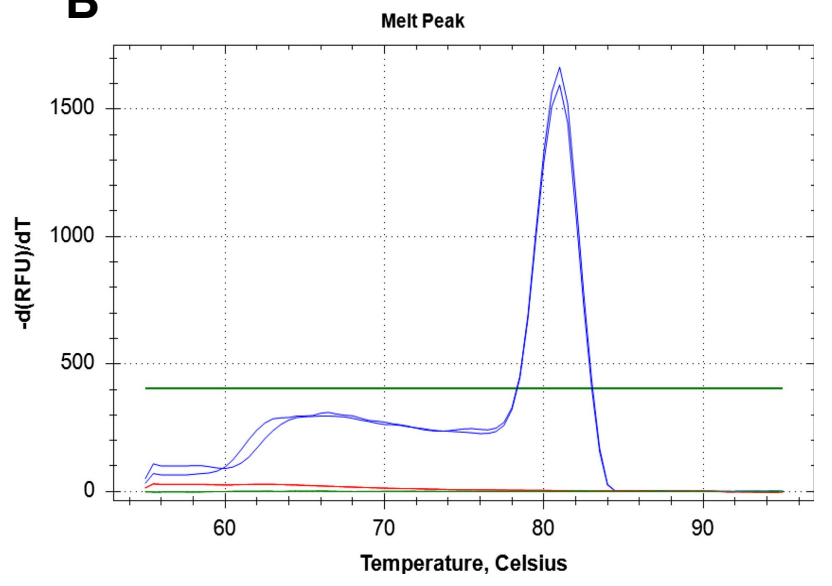

E
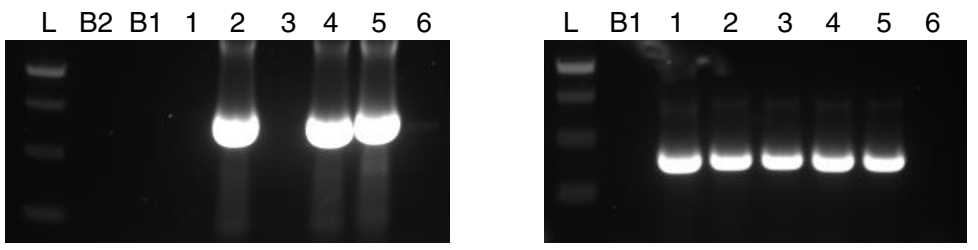

FIGURE 3

Specificity of the quantitative reverse-transcription PCR (qPCR) and nested reverse-transcription PCR (nRT-PCR) assays. A, Melt curve peak analysis of the qPCR assay with a tobacco streak virus (TSV)-infected soybean sample (W101-4, blue line), pGEM-T-TSV standards (Std-7 and Std-8, black line), soybean vein necrosis virus-positive sample (Ar2, light blue line), no-template control (green line), and no-reverse transcription control (purple line). B, Melt curve peak analysis of the qPCR assay with TSV-infected soybean sample (W101-4, blue line) a healthy soybean sample (DwNT1, red line) and a no-template control (green line). C, Specificity of the $n R T-P C R$ assay via gel electrophoresis, with first-round nRT-PCR; $D$, second-round $n R T-P C R ;$ and $E$, soybean elongation factor $1-\beta$ amplification as a control for RNA quality and complementary DNA synthesis. Lane $L=1-\mathrm{kb}$ molecular ladder; lanes B2 and B1 = nuclease-free water controls; lane 1 = DwNT1; lane 2 = 413; lane 3 = 423; lane 4 = SB5; lane 5 = W101-4; and lane 6 = no-reverse transcription control. 
from nonspecific amplification (Bustin et al. 2009; Taylor et al. 2010). The average efficiency of the WI qPCR assay was $94 \%$, which falls within the optimal range and indicates that the product doubled in each cycle (Bustin et al. 2009; Taylor et al. 2010). Therefore, the WI qPCR assay is efficient at amplifying the TSV CP gene for isolates examined in this study in a reproducible manner.

Primer specificity is key to any amplification-based diagnostic test. Increased annealing temperatures have been shown to improve specificity of primers (Korbie and Mattick 2008). This effect was also observed in the WI qPCR assay, where an increased annealing or extension temperature reduced the background signal produced from reactions with no template. The melt curve peak analysis showed that a single product was formed and further confirmed the specificity of the primers. Therefore, increasing the annealing or extension temperature decreased the likelihood of a false-positive detection using this assay without sacrificing its sensitivity. The specificity of the WI qPCR and nRT-PCR assays to amplify TSV was assessed by Sanger sequencing the PCR products, where the resulting sequences had high similarity to published sequences of the TSV CP gene. Furthermore, a healthy control sample and samples that were previously confirmed to be infected with other viruses of soybean were negative in the WI qPCR and nRT-PCR assays. These results show that both assays described in this study do not cross-react with other common soybean viruses or native soybean genes and are specific for detecting TSV.

With two specific and robust assays to detect TSV in soybean originating in Wisconsin, TSV-like or virus-like symptomatic and asymptomatic samples from around the state were assessed for the presence of TSV. TSV was confirmed in $47 \%$ of the samples using the WI qPCR assay. However, 91\% of symptomatic samples were positive for TSV in the nRT-PCR. The disparity of detection between the assays suggests that the samples that were TSV negative in the WI qPCR assay could have had lower titers of TSV, as has been reported for other ilarviruses (Osman et al. 2014; Untiveros et al. 2010), and were below the limit of detection. The nesting of the primers in the nRT-PCR increases sensitivity (Goode et al. 2002; Shen 2019) and could explain why this assay detected TSV in more samples than the WI qPCR assay. Furthermore, the high annealing temperature of the WI qPCR assay used to improve its accuracy may have decreased its sensitivity, though this was not apparent in our results.

Previously, Dutta et al. (2015) reported qPCR primers (Dutta qPCR) for the detection of TSV isolates from Oklahoma that could not be detected with serological tests. Wisconsin soybean samples were tested with the Dutta qPCR primers to compare the assay with the WI qPCR and nRTPCR assays described in this study. The majority of the samples confirmed TSV positive either by the WI qPCR or the nRT-PCR were TSV negative using the Dutta qPCR assay, and only three samples were positive in all of the assays. Based on these results, we determined that the Dutta qPCR assay cannot reliably detect the particular genotype of TSV in the samples from Wisconsin. It is possible that the WI qPCR or nRT-PCR assays may not detect TSV in samples from other states because this was not assessed in our study. Interestingly, the asymptomatic sample 423 from Wisconsin was positive only using the Dutta qPCR assay but not with the WI

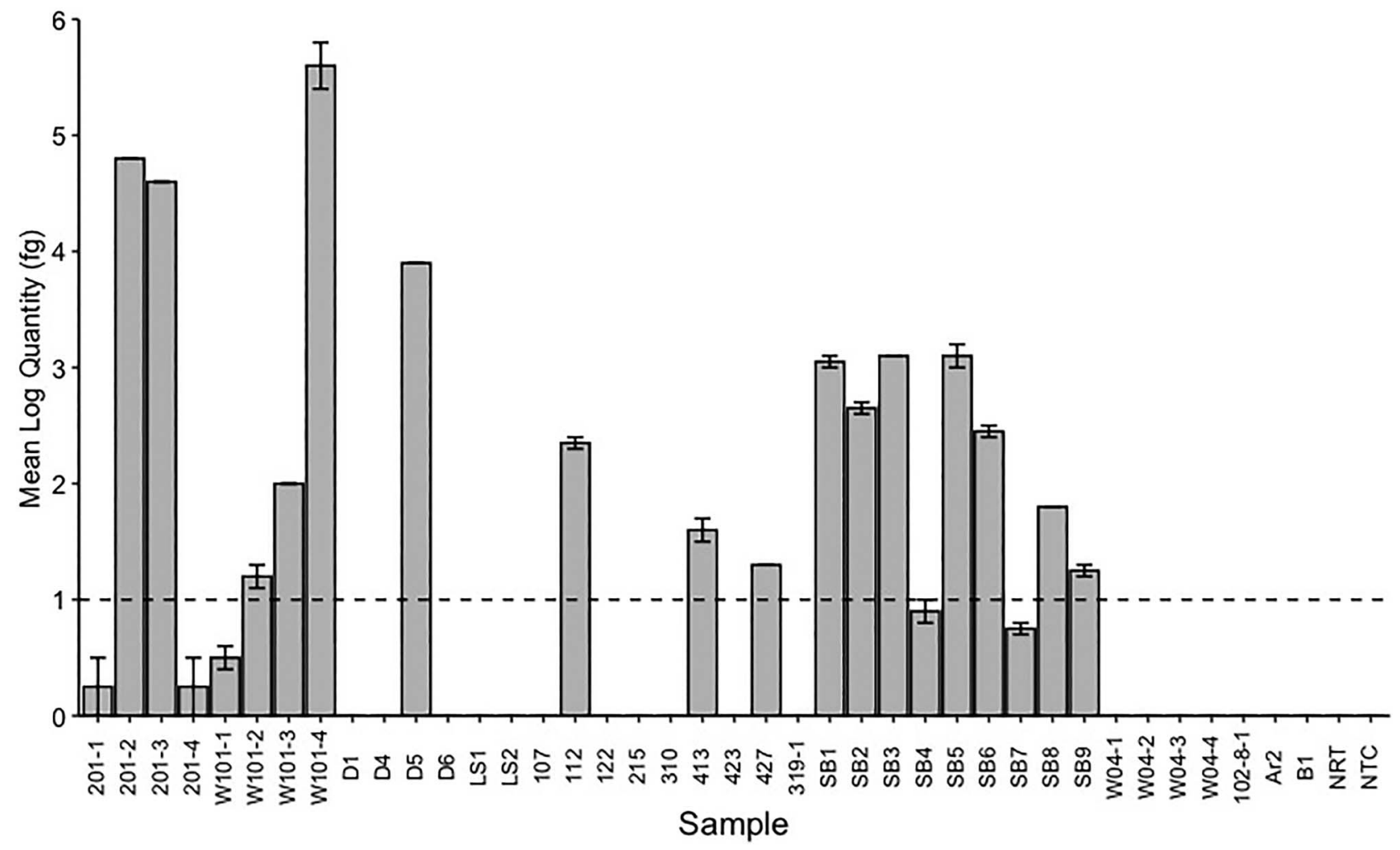

FIGURE 4

Titer of tobacco streak virus (TSV) in symptomatic, nonsymptomatic, or virus-confirmed soybean samples. Mean log quantity determined by calculating the log of the target concentration (in femtograms) compared with pGEM-T-TSV standard dilutions. Dashed line indicates limit of detection at $10 \mathrm{fg}$. Samples: 102-8-1 = alfalfa mosaic virus-positive control, Ar2 = soybean vein necrosis viruspositive control, B1 = bean pod mottle virus-positive control, NRT = no-reverse-transcription control, and NTC = nuclease-free water (no-template) control. 
qPCR or nRT-PCR assay. This finding suggests that sample 423 was an asymptomatic infection of a putatively different strain of TSV than the rest of the samples from Wisconsin. Furthermore, the lack of detection of the majority of samples from Wisconsin using the Dutta qPCR suggests that the differences in results may be due to the genetic differences in the TSV population (e.g., Wisconsin strains versus Oklahoma strains). Although the results from assays with two different chemistries (qPCR versus nRT-PCR) were compared, we have demonstrated an improved sensitivity for detecting the TSV genotype from Wisconsin with the WI qPCR and nRT-PCR assays.

Molecular diagnostic tools that provide reliable and accurate pathogen detection can aid in disease management decisions and implementation (Lévesque 2001; Rubio et al. 2020). In this study, we developed a qPCR assay and an nRT-PCR assay that are robust and can be used together as valuable tools to detect or quantify TSV. Current soybean disease management recommendations for TSV are to plant disease-free seed and rogue infected plants (Mueller et al. 2016). The nRTPCR and WI qPCR assay can be used to monitor TSV infection in soybean fields and rogue infected plants to avoid yield loss and maintain seed production fields free from the virus. Another strategy to control viruses is to use resistant cultivars (Rubio et al. 2020); however, information about resistance to TSV is scarce in soybean germplasm or cultivars (Hobbs et al. 2012; Rabedeaux et al. 2005; Wang et al. 2005). Viral load quantification can provide information about resistance levels in germplasm and cultivars (Rubio et al. 2020). The WI qPCR assay can be applied as a screening tool to quantify the titer of TSV in germplasm collections or in breeding programs during the development of soybean cultivars (Rubio et al. 2020; Shirima et al. 2017). The WI qPCR and nRT-PCR assays from this study are reliable and sensitive diagnostic tools for the detection or quantification of TSV in soybean. Implementation of the assays can help with disease management decisions, assessing virus spread, screening sources of TSV resistant germplasm or cultivars, maintaining healthy seed production fields, and providing valuable information to farmers about their potential risk of soybean yield loss due to TSV.

\section{ACKNOWLEDGMENTS}

We thank the Plant Disease Diagnostic Clinic at the University of Wisconsin-Madison (https://pddc.wisc.edu/) for providing a portion of the samples that were used for the development of the assays and A. Ranjan for facilitating the soybean elongation factor primer set.

\section{LITERATURE CITED}

Abtahi, F. S., and Motlagh, M. K. 2009. Tobacco streak virus isolated from lettuce. Pak. J. Biol. Sci. 12:707-711.

Ali, A. 2017. Rapid detection of fifteen known soybean viruses by dotimmunobinding assay. J. Virol. Methods 249:126-129.

Allen, T. W., Bradley, C. A., Sisson, A. J., Byamukama, E., Chilvers, M. I., Coker, C. M., Collins, A. A., Damicone, J. P., Dorrance, A. E., Dufault, N. S., Esker, P. D., Faske, T. R., Giesler, L. J., Grybauskas, A. P., Hershman, D. E., Hollier, C. A., Isakeit, T., Jardine, D. J., Kelly, H. M., Kemerait, R. C., Kleczewski, N. M., Koenning, S. R., Kurle, J. E., Malvick, D. K., Markell, S. G., Mehl, H. L., Mueller, D. S., Mueller, J. D., Mulrooney, R. P., Nelson, B. D., Newman, M. A., Osborne, L., Overstreet, C., Padgett, G. B., Phipps, P. M., Price, P. P., Sikora, E. J., Smith, D. L., Spurlock, T. N., Tande, C. A., Tenuta, A. U., Wise, K. A., and Wrather, J. A.
2017. Soybean yield loss estimates due to diseases in the United States and Ontario, Canada, from 2010 to 2014. Plant Health Prog. 18:19-27.

Almeida, Á. M. R., and Corso, I. C. 1991. Effect of sowing time on the incidence of bud blight in soybean (Glycine max L. Merr.). J. Phytopathol. 132:251-257.

Bandara, A. Y., Weerasooriya, D. K., Bradley, C. A., Allen, T. W., and Esker, P. D. 2020. Dissecting the economic impact of soybean diseases in the United States over two decades. PLoS One 15:e0231141.

Bol, J. F. 1999. Alfalfa mosaic virus and ilarviruses: Involvement of coat protein in multiple steps of the replication cycle. J. Gen. Virol. 80:1089-1102.

Boonham, N., Glover, R., Tomlinson, J., and Mumford, R. 2008. Exploiting generic platform technologies for the detection and identification of plant pathogens. Eur. J. Plant Pathol. 121:355-363.

Bujarski, J., Gallitelli, D., García-Arenal, F., Pallás, V., Palukaitis, P., Reddy, M. K., and Wang, A. 2019. ICTV virus taxonomy profile: Bromoviridae. J. Gen. Virol. 100:1206-1207.

Bustin, S. A., Benes, V., Garson, J. A., Hellemans, J., Huggett, J., Kubista, M., Mueller, R., Nolan, T., Pfaffl, M. W., Shipley, G. L., Vandesompele, J., and Wittwer, C. T. 2009. The MIQE guidelines: Minimum information for publication of quantitative real-time PCR experiments. Clin. Chem. 55:611-622.

Card, S. D., Pearson, M. N., and Clover, G. R. G. 2007. Plant pathogens transmitted by pollen. Australas. Plant Pathol. 36:455-461.

Cornelissen, B. J. C., Janssen, H., Zuidema, D., and Bol, J. F. 1984 Complete nucleotide sequence of tobacco streak virus RNA 3. Nucleic Acids Res. 12:2427-2437.

Costa, A. S., Miyasaka, S., and Pinto, A. J. D. 1955. Queima dos brotos da soja, uma moléstia causada pelo vírus da necrose branca ou couve [Soja bud blight, a disease caused by the Brazilian tobacco streak virus]. Bragantia 14:VII-X.

Dijkstra, J. 1983. Tobacco streak virus in sunflower (Helianthus annuиs). Neth. J. Plant Pathol. 89:153-169.

Dutta, M., Ali, A., and Melcher, U. 2015. Detection, discrimination and discovery of a new Tobacco streak virus strain. J. Virol. Methods 221:15-21.

Fagbenle, H. H., and Ford, R. E. 1970. Tobacco streak virus isolated from soybeans, Glycine max. Phytopathology 60:814-820.

FAOSTAT. 2018. Production: Countries by commodity. Food and Agriculture Organization of the United Nations. http://www.fao.org/ faostat/en/\#rankings/countries_by_commodity

Ge, X., Scott, S. W., and Zimmerman, M. T. 1997. The complete sequence of the genomic RNAs of spinach latent virus. Arch. Virol. 142:1213-1226.

Ghanekar, A. M., and Schwenk, F. W. 1974. Seed transmission and distribution of tobacco streak virus in six cultivars of soybeans. Phytopathology 64:112-114.

Goode, T., Ho, W.-Z., O’Connor, T., Busteed, S., Douglas, S. D., Shanahan, F., and O'Connell, J. 2002. Nested RT-PCR: Sensitivity controls are essential to determine the biological significance of detected mRNA. Pages 65-79 in: RT-PCR Protocols. J. O’Connell, ed. Humana Press, Towota, NJ, U.S.A.

Gracia, O., and Feldman, J. M. 1974. Tobacco streak virus in pepper. J. Phytopathol. 80:313-323.

Hobbs, H. A., Herman, T. K., Slaminko, T. L., Wang, Y., Nguyen, B. T., McCoppin, N. K., Domier, L. L., and Hartman, G. L. 2010. Occurrences of soybean viruses, fungal diseases, and pests in Illinois soybean rust sentinel plots. Plant Health Prog. 11. https://apsjournals. apsnet.org/doi/10.1094/PHP-2010-0827-01-BR

Hobbs, H. A., Jossey, S., Wang, Y., Hartman, G. L., and Domier, L. L. 2012. Diverse soybean accessions identified with temperature-sensitive resistance to tobacco streak virus. Crop Sci. 52:738-744.

Irizarry, M. D., Pathology, P., Groves, C. L., and Pathology, P. 2016. Re-emergence of Tobacco streak virus infecting Soybean in the United States and Canada. Plant Health Prog. 17:92-94.

Johnson, F. 1943. Soybean streak in Ohio. Plant Dis. Rep. 27:86-87.

Johnson, J. 1936. Tobacco streak, a virus disease. Phytopathology 26:285292.

Kaiser, W. J., Wyatt, S. D., and Klein, R. E. 1991. Epidemiology and seed transmission of two tobacco streak virus pathotypes associated 
with seed increases of legume germ plasm in eastern Washington. Plant Dis. 75:258-264.

Kaiser, W. J., Wyatt, S. D., and Pesho, G. R. 1982. Natural hosts and vectors of Tobacco streak virus in Eastern Washington. Phytopathology 72:1508-1512.

Klose, M. J., Sdoodee, R., Teakle, D. S., Milne, J. R., Greber, R. S., and Walter, G. H. 1996. Transmission of three strains of tobacco streak ilarvirus by different thrips species using virus-infected pollen. J. Phytopathol. 144:281-284.

Korbie, D. J., and Mattick, J. S. 2008. Touchdown PCR for increased specificity and sensitivity in PCR amplification. Nat. Protoc. 3:1452-1456.

Lévesque, C. A. 2001. Molecular methods for detection of plant pathogens-What is the future? Can. J. Plant Pathol. 23:333-336.

Martin, R. R., James, D., and Lévesque, C. A. 2000. Impacts of molecular diagnostic technologies on plant disease management. Annu. Rev. Phytopathol. 38:207-239.

Melhus, I. E. 1942. Soybean diseases in Iowa in 1942. Plant Dis. Rep. 26:431-434.

Mink, G. I. 1992. Ilarvirus vectors. Pages 261-281 in: Advances in Disease Vector Research. K. F. Harris, ed. Springer, New York, NY, U.S.A.

Mink, G. I. 1993. Pollen- and seed-transmitted viruses and viroids. Ann. Appl. Biol. 31:375-402.

Mueller, D., Wise, K., Sisson, A., Smith, D., Sikora, E., Bradley, C., and Robertson, A. 2016. Foliar diseases. Pages 37-74 in: A Farmer's Guide to Soybean Diseases. D. Mueller, K. Wise, A. Sisson, D. Smith, E. Sikora, C. Bradley, and A. Robertson, eds. American Phytopathological Society, St. Paul, MN, U.S.A.

Osman, F., Al Rwahnih, M., and Rowhani, A. 2014. Improved detection of ilarviruses and nepoviruses affecting fruit trees using quantitative RT-qPCR. J. Plant Pathol. 96:577-583.

Padmanabhan, C., Gao, S., Li, R., Zhang, S., Fei, Z., and Ling, K. S. 2014. Complete genome sequence of an emerging genotype of tobacco streak virus in the United States. Genome Announce. 2:e01138-14.

Pallas, V., Aparicio, F., Herranz, M. C., Amari, K., Sanchez-Pina, M. A., Myrta, A., and Sanchez-Navarro, J. A. 2012. Ilarviruses of Prunus spp.: A continued concern for fruit trees. Phytopathology 102:11081120.

Pallas, V., Aparicio, F., Herranz, M. C., Sanchez-Navarro, J. A., and Scott, S. W. 2013. The Molecular Biology of Ilarviruses. Pages 139181 in: Advances for Virus Research. K. Maramorosch and F. A. Murphy, eds. Academic Press, Cambridge, MA, U.S.A.

Pfaffl, M. W. 2001. A new mathematical model for relative quantification in real-time RT-PCR. Nucleic Acids Res. 29:e45.

Prasada Rao, R. D. V. J., Reddy, A. S., Reddy, S. V., Thirumala-Devi, K., Chander Rao, S., Manoj Kumar, V., Subramaniam, K., Reddy, T. Y., Nigam, S. N., and Reddy, D. V. R. 2003. The host range of Tobacco streak virus in India and transmission by thrips. Ann. Appl. Biol. 142:365-368.

Rabedeaux, P. F., Gaska, J. M., Kurtzweil, N. C., and Grau, C. R. 2005. Seasonal progression and agronomic impact of Tobacco streak virus on soybean in Wisconsin. Plant Dis. 89:391-396.

Rozen, S., and Skaletsky, H. 2000. Primer3 on the WWW for general users and for biologist programmers. Pages 365-386 in: Bioinformatics Methods and Protocols. Methods in Molecular Biology. S. Misener and S. A. Krawetz, eds. Humana Press, Towota, NJ, U.S.A.

Rubio, L., Galipienso, L., and Ferriol, I. 2020. Detection of plant viruses and disease management: Relevance of genetic diversity and evolution. Front. Plant Sci. 11:1092.

Schneider, W. L., Sherman, D. J., Stone, A. L., Damsteegt, V. D., and Frederick, R. D. 2004. Specific detection and quantification of Plum pox virus by real-time fluorescent reverse transcription-PCR. J. Virol. Methods 120:97-105.

Scott, S. W., Zimmerman, M. T., and Ge, X. 1998. The sequence of RNA 1 and RNA 2 of tobacco streak virus: Additional evidence for the inclusion of alfalfa mosaic virus in the genus Ilarvirus. Arch. Virol. 143:1187-1198.
Sdoodee, R., and Teakle, D. S. 1987. Transmission of tobacco streak virus by Thrips tabaci a new method of plant virus transmission. Plant Pathol. 36:377-380.

Sdoodee, R., and Teakle, D. S. 1993. Studies on the mechanism of transmission of pollen-associated tobacco streak ilarvirus virus by Thrips tabaci. Plant Pathol. 42:88-92.

Sharman, M., Thomas, J. E., and Persley, D. M. 2008. First report of Tobacco streak virus in sunflower (Helianthus annuus), cotton (Gossypium hirsutum), chickpea (Cicer arietinum) and mung bean (Vigna radiata) in Australia. Australas. Plant Dis. Notes 3:27-29.

Sharman, M., Thomas, J. E., and Persley, D. M. 2015. Natural host range, thrips and seed transmission of distinct Tobacco streak virus strains in Queensland, Australia. Ann. Appl. Biol. 167:197-207.

Shen, C.-H. 2019. Amplification of nucleic acids. Page 215-247 in: Diagnostic Molecular Biology. C.-H. Shen, ed. Academic Press, Cambridge, MA, U.S.A.

Sherwood, J. L., and Jackson, K. E. 1985. Tobacco streak virus in soybean in Oklahoma. Plant Dis. 69:727.

Shirima, R. R., Maeda, D. G., Kanju, E., Ceasar, G., Tibazarwa, F. I., and Legg, J. P. 2017. Absolute quantification of cassava brown streak virus mRNA by real-time qPCR. J. Virol. Methods 245:5-13.

Sivaprasad, Y., Bhaskara Reddy, B. V., Rekha Rani, K., Raja Reddy, K., and Sai Gopal, D. V. R. 2010. First report of Tobacco streak ilarvirus infecting onion (Allium cepa). New Dis. Rep. 22:17.

Staroscik, A. 2004. Calculator for determining the number of copies of a template. University of Rhode Island Genomics Sequencing Center. https://cels.uri.edu/gsc/cndna.html

Taylor, S., Wakem, M., Dijkman, G., Alsarraj, M., and Nguyen, M. 2010. A practical approach to RT-qPCR-Publishing data that conform to the MIQE guidelines. Methods 50:S1-S5.

Untiveros, M., Perez-Egusquiza, Z., and Clover, G. 2010. PCR assays for the detection of members of the genus Ilarvirus and family Bromoviridae. J. Virol. Methods 165:97-104.

USDA-NASS. 2019. Statistics by Subject. United States Department of Agriculture-National Agricultural Statistics Service. https://www.nass. usda.gov/Statistics_by_Subject/

van Vloten-doting, L. 1975. Coat protein is required for infectivity of tobacco streak virus: Biological equivalence of the coat proteins of tobacco streak and alfalfa mosaic viruses. Virology 65:215-225.

Vemana, K., Goud, T. E. S., Reddy, D. L., Venkateswarlu, N. C., Naik, K. S. S., Kumar, D. S., Padma latha, Y., and Desai, S. 2014 First report of Tobacco streak virus infecting pigeon pea (Cajanus cajan) in India. Plant Dis. 98:287.

Vemana, K., and Jain, R. K. 2010. New experimental hosts of Tobacco streak virus and absence of true seed transmission in leguminous hosts. Indian J. Virol. 21:117-127.

Vinodkumar, S., Nakkeeran, S., Malathi, V. G., Karthikeyan, G., Amala Balu, P., Mohankumar, S., and Renukadevi, P. 2017. Tobacco streak virus: An emerging threat to cotton cultivation in India. Phytoparasitica 45:729-743.

Wang, Y., Hobbs, H. A., Hill, C. B., Domier, L. L., Hartman, G. L., and Nelson, R. L. 2005. Evaluation of ancestral lines of U.S. soybean cultivars for resistance to four soybean viruses. Crop Sci. 45:639-644.

Wells-Hansen, L. D., Polashock, J. J., Vorsa, N., Lockhart, B. E. L., and McManus, P. S. 2016. Identification of Tobacco streak virus in cranberry and the association of TSV with berry scarring. Plant Dis. 100:696-703.

Wrather, A., and Koenning, S. 2009. Effects of diseases on soybean yields in the United States 1996 to 2007. Plant Health Prog. 10. https:// apsjournals.apsnet.org/doi/10.1094/PHP-2009-0401-01-RS

Xin, H. W., Ji, L. H., Scott, S. W., Symons, R. H., and Ding, S. W. 1998. Ilarviruses encode a cucumovirus-like $2 b$ gene that is absent in other genera within the Bromoviridae. J. Virol. 72:6956-6959.

$\mathrm{Xu}, \mathrm{H}$., and Nie, J. 2006. Identification, characterization, and molecular detection of Alfalfa mosaic virus in potato. Phytopathology 96:12371242. 